\title{
Scientific Writing Coaching Class for Teachers in Sibolga City
}

\author{
Saharman Gea ${ }^{*}$, T. Alief Aththorick ${ }^{2}$, Sovia Lenny ${ }^{1}$, Yuan Alfinsyah Sihombing ${ }^{3}$, Khatarina \\ Meldawati Pasaribu' ${ }^{1}$, Averrous Fazlurrahman Piliang ${ }^{3}$ \\ ${ }^{1}$ Department of Chemistry, Faculty of Mathematics and Natural Science, Universitas \\ Sumatera Utara \\ ${ }^{1}$ Department of Biology, Faculty of Mathematics and Natural Science, Universitas Sumatera \\ Utara \\ ${ }^{1}$ Department of Physics, Faculty of Mathematics and Natural Science, Universitas Sumatera \\ Utara \\ *Email: s.gea@usu.ac.id
}

\begin{abstract}
Referring to Ministerial Regulation of PAN-RB No. 16 of 2009 on Teacher Functional Status and Credit Score, it is clearly mentioned that one of the key components to apply teacher promotion is scientific writing (KTI). However, in fact, it was found that many teachers were independently constrained, especially in Sibolga City. As a result, the chance to get a higher rank and to be placed would be hampered. In addition, even some teachers are caught up in taking shortcuts by using the third part services to prepare their scientific writing, which of course, are not acceptable in publication ethics and academic values. In line with the results of preliminary observations made by the team, it was noticed that the teachers writing ability can be improved by providing them writing coaching class, including explanations and even training materials that need to be used in scientific writing. This writing coaching class is intended to provide teachers an opportunity to develop their skills, especially skill to write down scientific papers. Writing coaching class will be done by encouraging teachers to compose their ideas, formulating their problems, obtaining references sources, providing consultation rooms, implementing ethics and scientific publishing regulation, and selecting places where scientific papers will be published.
\end{abstract}

\section{Keyword: writing ideas, scientific papers, publication ethics, scientific regulations}

\begin{abstract}
Abstrak
Merujuk pada Peraturan Menteri PAN-RB No. 16 Tahun 2009 tentang Jabatan Fungsional Guru dan Angka Kredit, dengan jelas dinyatakan bahwa karya tulis ilmiah (KTI) adalah salah satu komponen utama dalam pengajuan pangkat para guru. Namun di lapangan ditemukan tidak sedikit jumlah guru, khususnya di Kota Sibolga, yang terkendala secara mandiri melakukannya. Akibatnya kesempatan untuk mendapatkan pangkat dan jabatan yang lebih tinggi akan terhambat. Bahkan beberapa guru terjebak dalam mengambil jalan pintas dengan menggunakan jasa para pihak yang tidak bertanggungjawab yang menyediakan jasa tulisan yang sudah jadi, yang tentu saja, jauh dari etika publikasi dan kaidah akademik. Sesuai dengan hasil observasi awal yang dilakukan tim, ditemukan bahwa ketidakmampuan menulis guru-guru ini disebabkan kurangnya pembinaan, pemberian penjelasan dan juga sarana pelatihan untuk membiasakan menulis karya tulis ilmiah. Kegiatan ini dimaksudkan untuk memberi kesempatan bagi para guru meningkatkan ketrampilan mereka khususnya dalam membuat karya tulis ilmiah yang dimulai pada motivasi menulis, pencarian ide, perumusan masalah, mendapatkan sumber referensi dan cara mengaturnya, pemberian ruang konsultasi, pengenalan etika dan kaidah publikasi ilmiah dan pemilihan tempat dimana naskah karya tulis ilmiah akan diterbitkan. Kegiatan ini akan dilaksanakan oleh para dosen di lingkungan FMIPA USU dari berbagai disiplin ilmu dan telah berpengalaman dalam penulisan karya tulis ilmiah. Sebagai luaran dari kegiatan adalah buku saku berisi pedoman penulisan karya tulisan ilmiah bagi para guru, video kegiatan, dan publikasi pengabdian kepada masyarakat.
\end{abstract}

Kata Kunci: ide tulisan, karya tulis ilmiah, etika publikasi, kaidah ilmiah. 


\section{PENDAhUluan}

Kota Sibolga adalah salah kotamadya di Provinsi Sumatera Utara yang terletak di Pantai Barat Sumatera di kawasan Teluk Tapian Nauli pada posisi Lintang Utara $01^{\circ} 42^{\prime}-01^{\circ} 46^{\prime}$ dan Bujur Timur $98^{\circ} 46^{\prime}-98^{\circ} 48^{\prime}$ dengan jarak $\pm 350 \mathrm{~km}$ dari Medan dengan luas penduduk $\pm 10,77 \mathrm{~km}^{2}$ serta berpenduduk sekitar 97.000 jiwa. Kota Sibolga dipengaruhi oleh letaknya yaitu berada pada daratan pantai, lereng, dan pegunungan dengan ketinggian berkisar antara 0-150 meter dpl, dengan kemiringan lahan bervariasi antara 0-2 \% sampai lebih dari $40 \%$. Wilayah Administrasi Pemerintahan Kota Sibolga terdiri atas 4 kecamatan dan 17 kelurahan, yaitu Kecamatan Sibolga Utara terdiri dari 5 kelurahan, Kecamatan Sibolga Kota 4 kelurahan, Kecamatan Sibolga Selatan 4 kelurahan, dan Kecamatan Sibolga Sambas terdiri dari 4 kelurahan. Saat ini Sibolga memiliki 61 sekolah pendidikan tingkat dasar yang terdiri dari 56 Sekolah Dasar negeri dan swasta dan 5 Madrasah Ibtidaiyah negeri dan swasta. Jumlah guru keseluruhannya ada sebanyak 881 orang dengan 17.130 orang murid. Jumlah sekolah lanjutan tingkat pertama ada 18 sekolah yang terdiri dari 14 SLTP negeri dan swasta dan 4 MTS negeri dan swasta dengan jumlah guru dan murid seluruhnya masing- masing 443 guru dan banyaknya murid 7.479 murid. Sekolah lanjutan tingkat atas ada sebanyak 19 sekolah yang terdiri dari 8 SLTA negeri dan swasta, 3 MA negeri dan swasta dan 8 SMK negeri dan swasta.

Sebagai sebuah kota, permasalahan yang dihadapi warga Sibolga adalah sangat rumit dan berbelit diantaranya perihal kesehatan, ketersediaan lapangan kerja, ketimpangan sosial, pertumbuhan penduduk yang tak terkendali, masalah jender, pendidikan dan masalah turunan lainnya. Masalah pendidikan tentu mendapatkan perhatian khusus dan lebih rumit lagi mulai dari keterbatasan sarana dan prasarana, kurikulum, rasio siswa terhadap tenaga pengajar, dan kapasitas dari para pengajar. Kualitas para guru menjadi faktor penentu keberhasilan proses belajar-mengajar, diataranya kemampuan dalam menulis karya tulis ilmiah yang masih lemah. Salah satu inti yang dikehendaki dalam Peraturan Menteri PAN-RB No. 16 Tahun 2009 tentang Jabatan Fungsional Guru dan Angka Kredit adalah mendorong profesionalisme guru dalam melaksanakan tugas dan tanggungjawabnya. Hal ini dijabarkan dalam bentuk promosi jabatan/pangkat guru dengan capaian dan prestasi kerja meliputi: pendidikan, proses pembelajaran, pengembangan profesi dan penunjang proses pembelajaran. Khusus bidang pengembangan profesi, kegiatan yang termasuk di dalamnya adalah menyusun karya tulis ilmiah (KTI), teknologi tepat guna, penciptaan alat peraga/bimbingan, karya seni, dan pengembangan kurikulum. KTI adalah salah satu masalah besar yang menjadi kendala bagi para guru meningkatkan karir dan profesinya, termasuk guru-guru di Kota Sibolga.

\section{METODE PELAKSANAAN (METHODS)}

Berdasarkan permasalahan yang telah dikemukakan, metode pendekatan yang digunakan adalah metode sosialisasi (penyuluhan), diskusi, pelatihan penggunaan beberapa software terkait, konsultasi, pendampingan dan evaluasi.

Secara operasional metode pelaksanaan setiap masalah di atas adalah sebagai berikut:

a. Memberikan penyuluhan dan penjelasan berupa motivasi perlunya menulis bagi seorang guru, mendapatkan topik, dan cara mendapatkan sumber bacaan.

b. Memperkenalkan dan memberi pelatihan penggunaan software Mendeley untuk memberikan kemampuan mengatur daftar pustaka secara daring.

c. Memperkenalkan dan memberi pelatihan penggunaan software Origin 8.0 agar mampu menampilkan data dengan baik dan benar.

d. Memberi penjelasan struktur tulisan mulai dari Judul hingga daftar pustaka.

e. Memperkenalkan dan menjelaskan definisi plagiasi dan metode menghindarinya serta memberi pelatihan penggunaan software plagiarism checker. 
f. Memberikan penjelasan perihal etika penulisan karya tulis ilmiah. Membekali para guru bagaimana memilih penerbit yang sesuai dengan topik tulisan, membaca petunjuk bagi para penulis yang dikeluarkan oleh pihak penerbit serta proses pengiriman naskah.

g. Karena materi yang harus disampaikan terlalu banyak, tim USU akan menyiapkan buku saku yang berisi pedoman penulisan karya tulis ilmiah. Buku ini dibuat sedemikian rupa dalam bahasa yang mudah dipahami dan diikuti oleh para guru.

h. Memberi ruang konsultasi jarak jauh dan diskusi secara daring maupun off line.

i. Mengevaluasi setiap draft tulisan yang akan dikirimkan kepada penerbit sehingga akan memperkecil kemungkinan pihak editor akan menolak menerbitkannya.

Secara singkat solusi dari setiap masalah yang dihadapi mitra disampaikan pada Tabel 1 .

\begin{tabular}{|c|c|c|}
\hline No & Masalah & Solusi \\
\hline 1. & Motivasi menulis & $\begin{array}{l}\text { - Dijabarkan peraturan MENPAN-RB No. No. } 16 \\
\text { Tahun } 2009 \\
\text { - Didiskusikan hambatan mitra untuk membuat } \\
\text { karya tulis ilmiah } \\
\text { - Diberikan contoh-contoh guru yang sukses dalam } \\
\text { menulis karya tulis ilmiah baik di tingkat } \\
\text { Nasional maupun di tingkat wilayah } \\
\text { - Dijelaskan ancaman maraknya jual-beli tulisan } \\
\text { dari pihak yang tidak bertanggungjawab }\end{array}$ \\
\hline 2. & Pemilihan topik & $\begin{array}{l}\text { - Diberikan pemahanan tentang kriteria pemilihan } \\
\text { topik dan kesesuaiannya dengan latar belakang setiap } \\
\text { guru } \\
\text { - Setiap guru menentukan topik tulisannya sendiri dan } \\
\text { mendiskusikannya dengan pendamping } \\
\text { - Disampaikan cara berpikir yang inovatif }\end{array}$ \\
\hline 3. & Pencarian bahan bacaan & $\begin{array}{l}\text { - Diperkenalkan cara mencari sumber bacaan } \\
\text { - Pengoperasion Mendeley untuk mengatur bahan pustaka } \\
\text { - Dijelaskan definisi dari bahan bacaan yang up to date }\end{array}$ \\
\hline 4. & Struktur tulisan & $\begin{array}{l}\text { - Memperkenalkan bagian dari tulisan mulai dari } \\
\text { judul hingga daftar pustaka } \\
\text { - Authorship dan afiliasi } \\
\text { - Kontak penulis } \\
\text { - Penulisan abstrak yang benar } \\
\text { - Ucapan terimakasih }\end{array}$ \\
\hline 5. & $\begin{array}{l}\text { Mengenal plagiasi dan } \\
\text { cara menghindarinya }\end{array}$ & $\begin{array}{l}\text { - Defini dan jenis plagiasi } \\
\text { - Parafrase } \\
\text { - Diperkenalkan software pengecekan derajat plagiasi } \\
\text { - Batas similirity sebuah tulisan }\end{array}$ \\
\hline 6. & Penampilan data & $\begin{array}{l}\text { - Diperkenalkan software Origin } 8.0 \\
\text { - Dijelaskan model-model data yang dapat digunakan dan } \\
\text { alasan pemilihan model data yang ditampilkan }\end{array}$ \\
\hline 7. & Etika penulisan & $\begin{array}{l}\text { - Memperkenalkan } 10 \text { hal yang menjadi sumber } \\
\text { pelanggaran etika dalam penulisan karya ilmiah }\end{array}$ \\
\hline
\end{tabular}



8. Memilih penerbit
- Menentukan tujuan dari pembuatan tulisan
- Mengenal scope dari penerbit tulisan yang dituju
- Mengetahui gaya selingkung dari tulisan yang diterbitkan
- Mempelajari secara rinci aturan bagi penulis

Tabel 1. Solusi dari setiap masalah yang dihadapi mitra

\section{HASIL DAN PEMBAHASAN}

Hasil dan luaran yang dicapai sebagai hasil dari pelaksanaan program pengabdian ini adalah:

\section{Pelatihan kepada guru-guru}

Telah dilaksanakannya pelatihan secara langsung terhadap guru-guru yang mewakili beberapa sekolah di kawasan kota Sibolga secara langsung yang bertempat di SMP N 1 Kota Sibolga. Karena pelatihan dilaksanakan di tengah sedang merebaknya pandemi virus Covid 19, maka dilaksanakan serangkaian penyesuaian terhadap rencana yang telah disusun. Proses pelaksanaan pelatihan disesuaikan dengan mematuhi aturan protokol kesehatan dan mengikuti arahan gugus tugas covid 19 kota Sibolga. Namun dengan penyesuaian yang dilakukan, materi pelatihan yang telah disiapkan tetap dapat disampaikan dengan baik tanpa adanya kendala yang berarti.

Komunikasi yang berkesinambungan tetap dilaksanakan dengan pemangku kebijakan yang terdapat di Kota Sibolga untuk terus memetakan kendala yang dihadapi oleh guru-guru yang terdapat di Kota Sibolga terkait penulisan karya tulis ilmiah maupun bidang lainnya. Selain itu, komunikasi juga terus dijalin dengan peserta pelatihan terkait pengimplementasian ilmu yang didapat dari pelatihan dan kesiapan peserta untuk menjadi tutor bagi rekan guru lainnya di Kota Sibolga.

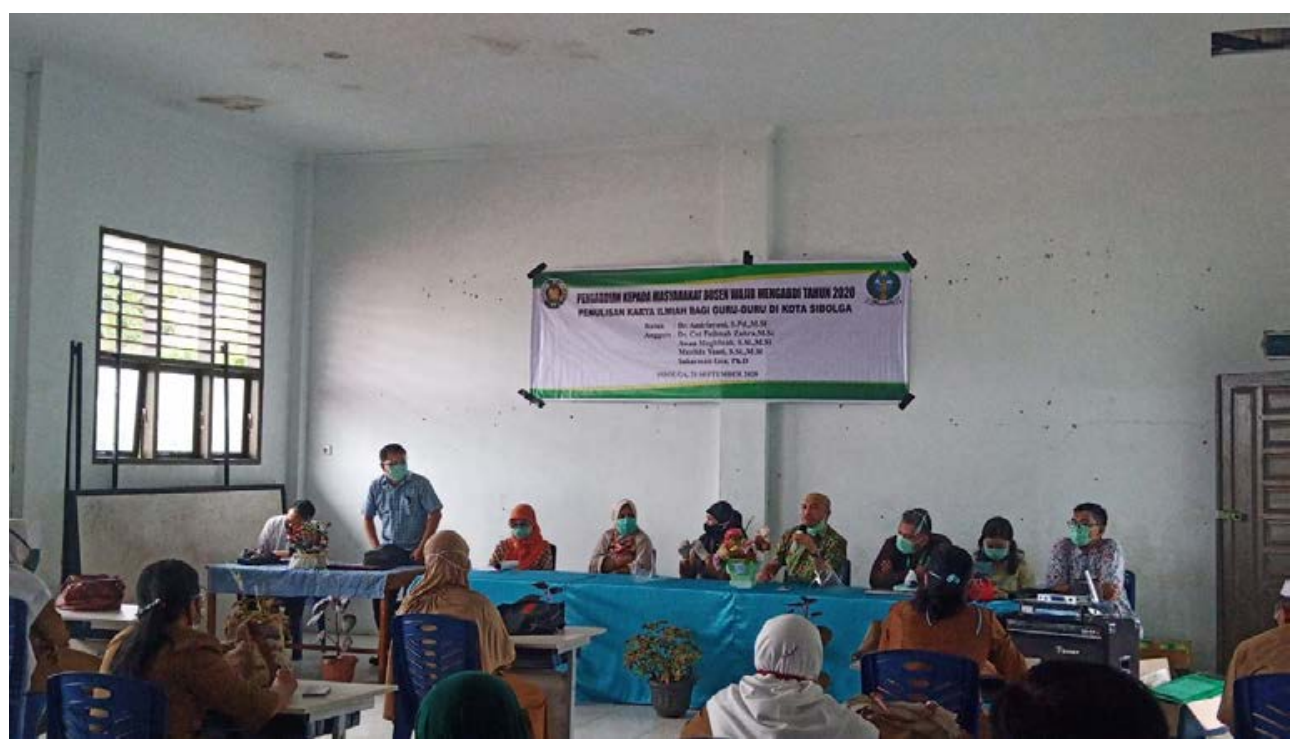

Gambar 3.1. Kata sambutan dari Saharman Gea, P.hD selaku ketua tim pengabdian 


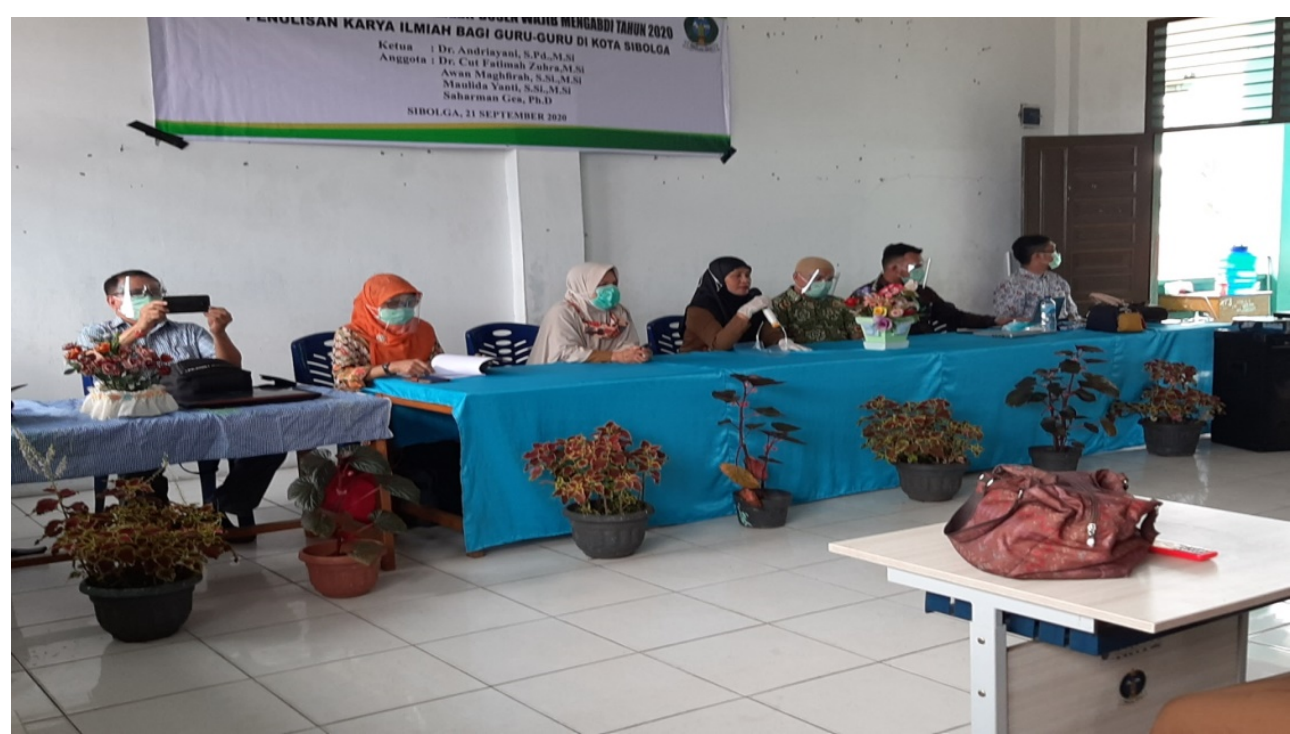

Gambar 3.2. Kata Sambutan dan Pembukaan oleh Dra. MASNOT, M.A selaku Kepala Dinas Pendidikan Sibolga

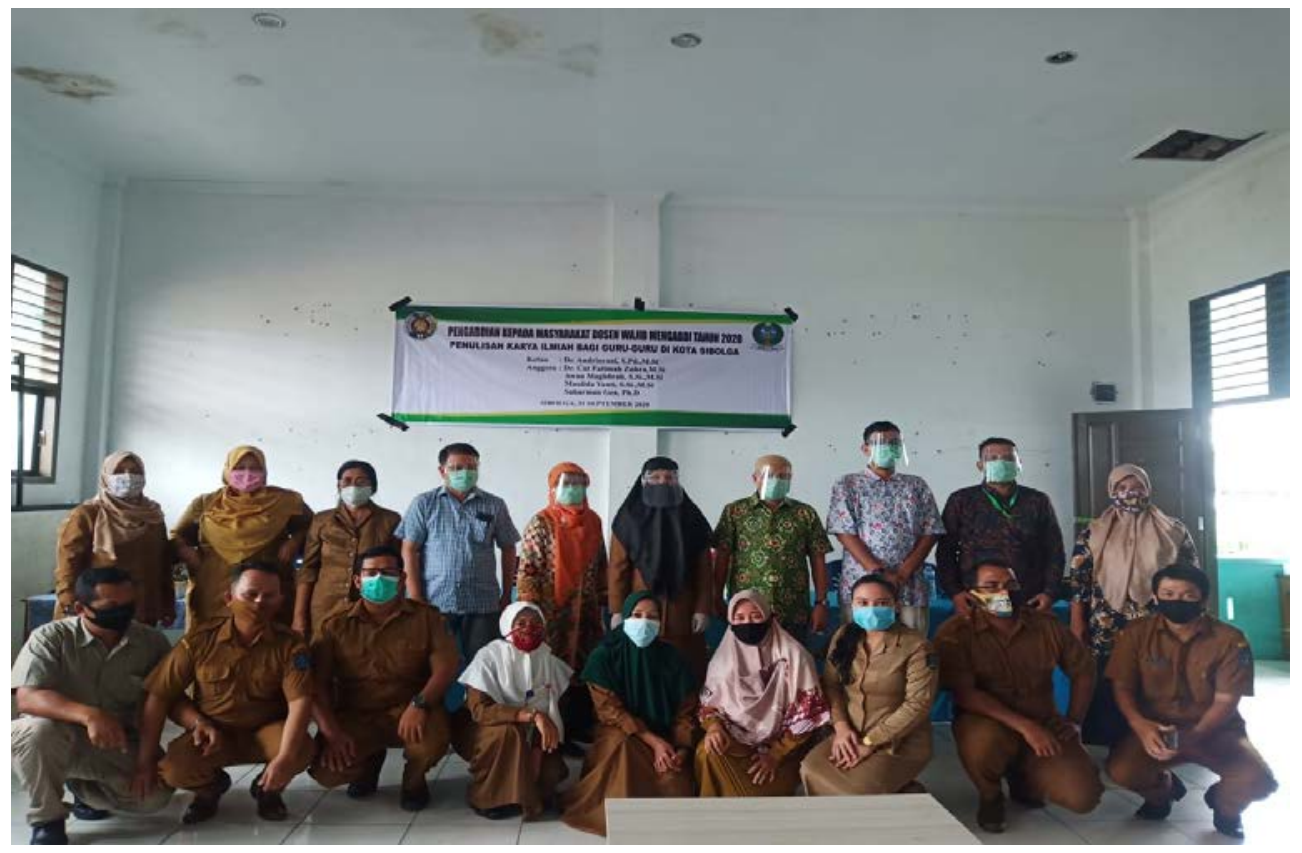

Gambar 3.3. Foto Bersama Peserta Pelatihan 


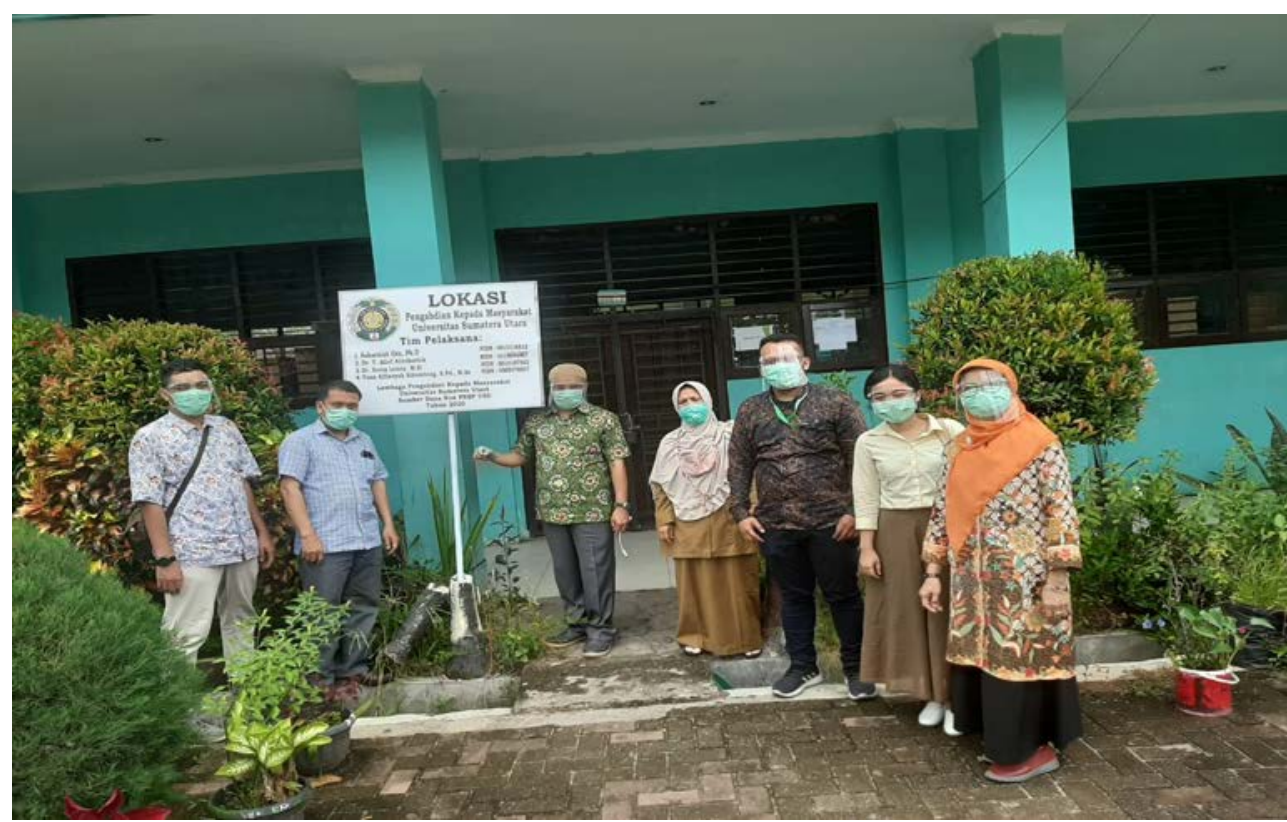

Gambar 3.4. Pemasangan Plang Pengabdian di SMP Negeri 1 Sibolga

\section{Media online/surat kabar}

Proses pelatihan yang dilaksanakan di Kota Sibolga mendapat kawalan ketat dari berbagai pihak seperti pemangku kebijakan dinas pendidikan kota setempat yang juga hadir memberikan kata sambutan sekaligus membuka acara, gugus tugas covid 19 Kota Sibolga, untuk memastikan pelaksanaan pelatihan dilakukan dengan mematuhi protokol kesehatan dan pihak media yang memantau, mendokumentasikan dan mempublikasikan proses jalannya pelatihan karya tulis ilmiah bagi guru-guru di Kota Sibolga. 


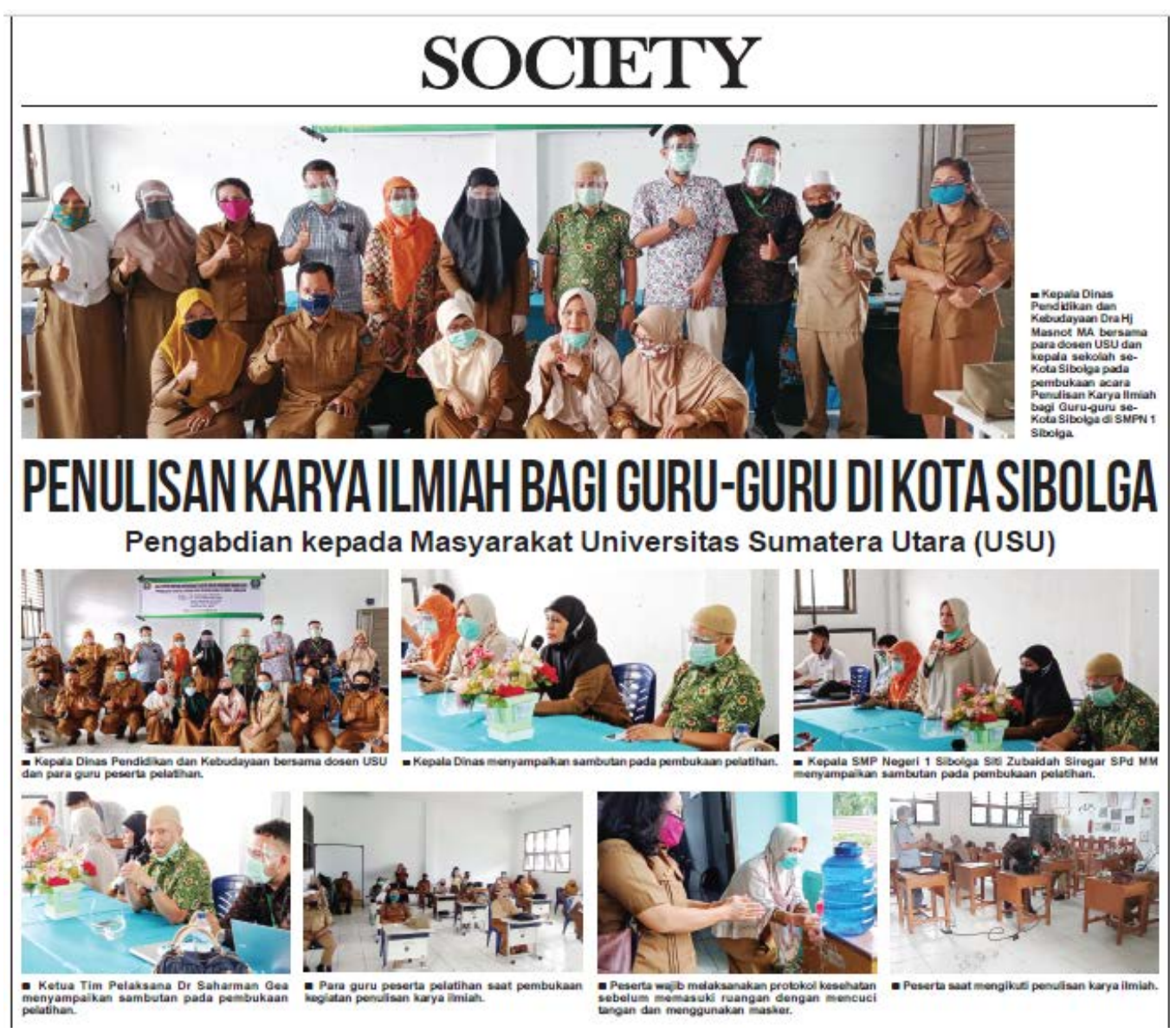

Gambar 3.5. Petikan Liputan Pelaksanaan Kegiatan pada Media Cetak

\section{Buku Saku Pedoman Penulisan Karya Ilmiah}

Sebagai bahan pedoman bagi guru dalam menulis karya ilmiah, selanjutnya bahan presentasi yang digunakan dalam pelatihan dicetak dan dibagikan kepada peserta untuk selanjutnya dapat digunakan untuk mengimplentasikan ilmu yang didapat dan sebagai referensi bagi guru dalam membagikan ilmu kepada rekan guru lainnya.
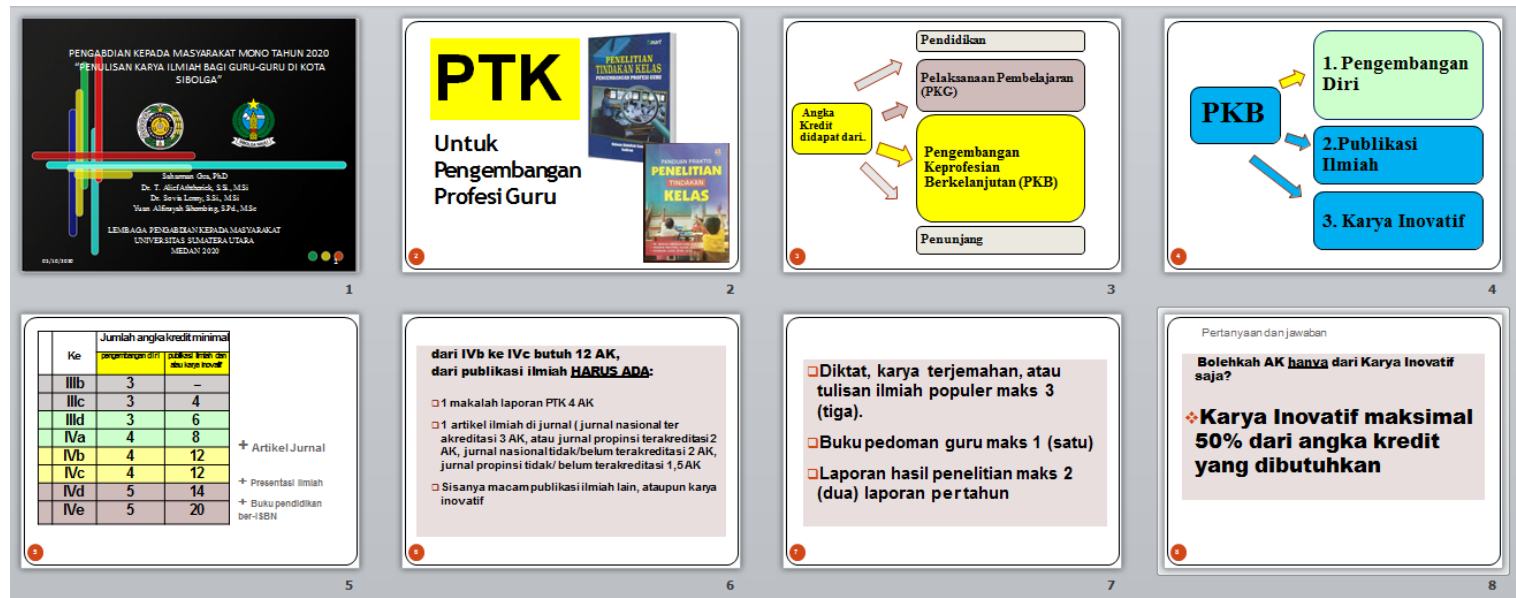

Gambar 3.6. Buku Saku Pedoman Penulisan Karya Ilmiah Bagian 1 
ISSN Printed Version: 2549-4341

ISSN Online Version: 2549-418X

Saharman Gea et al. Scientific Writing Coaching Class for Teachers in Sibolga City

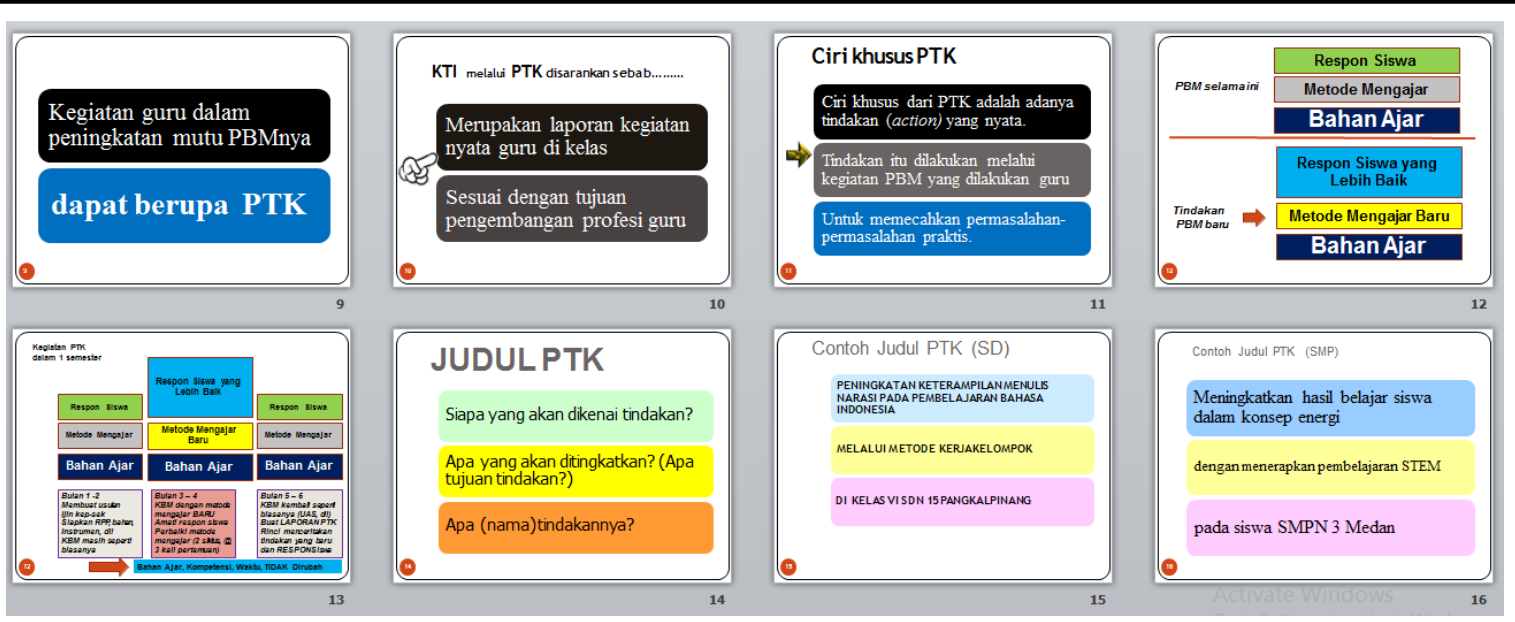

Gambar 3.7. Buku Saku Pedoman Penulisan Karya Ilmiah Bagian 2
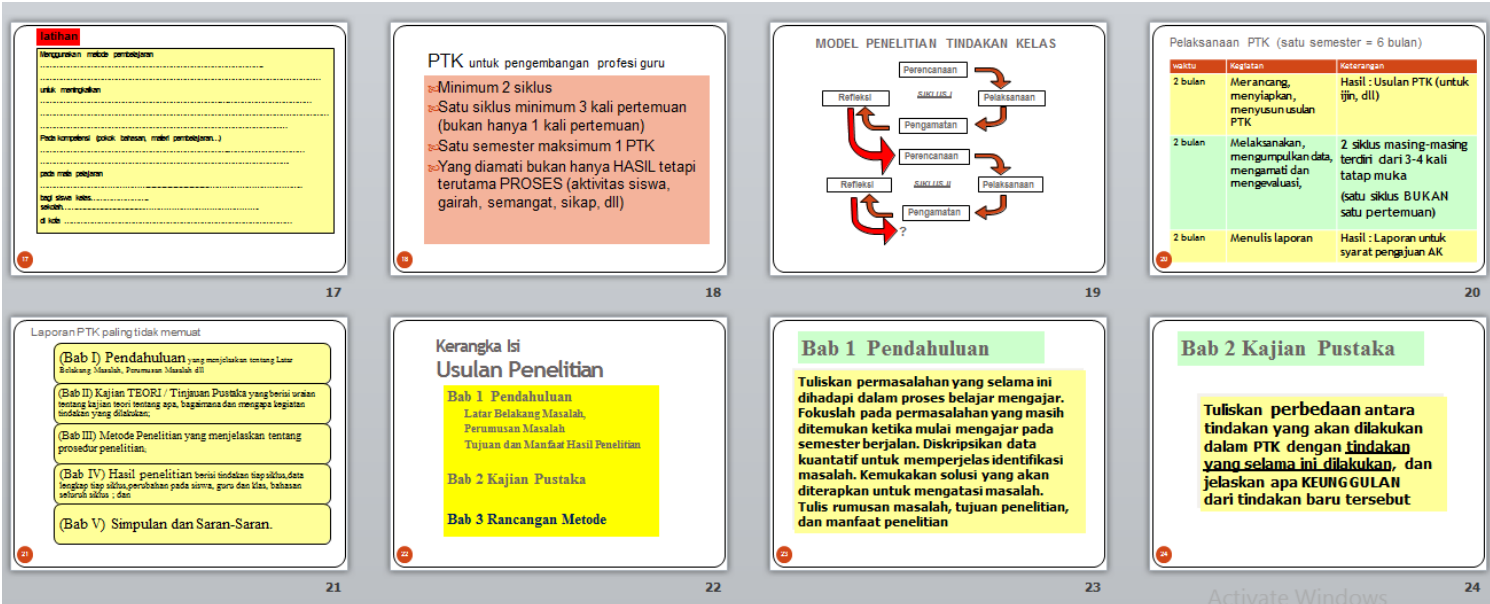

Gambar 3.8. Buku Saku Pedoman Penulisan Karya Ilmiah Bagian 3

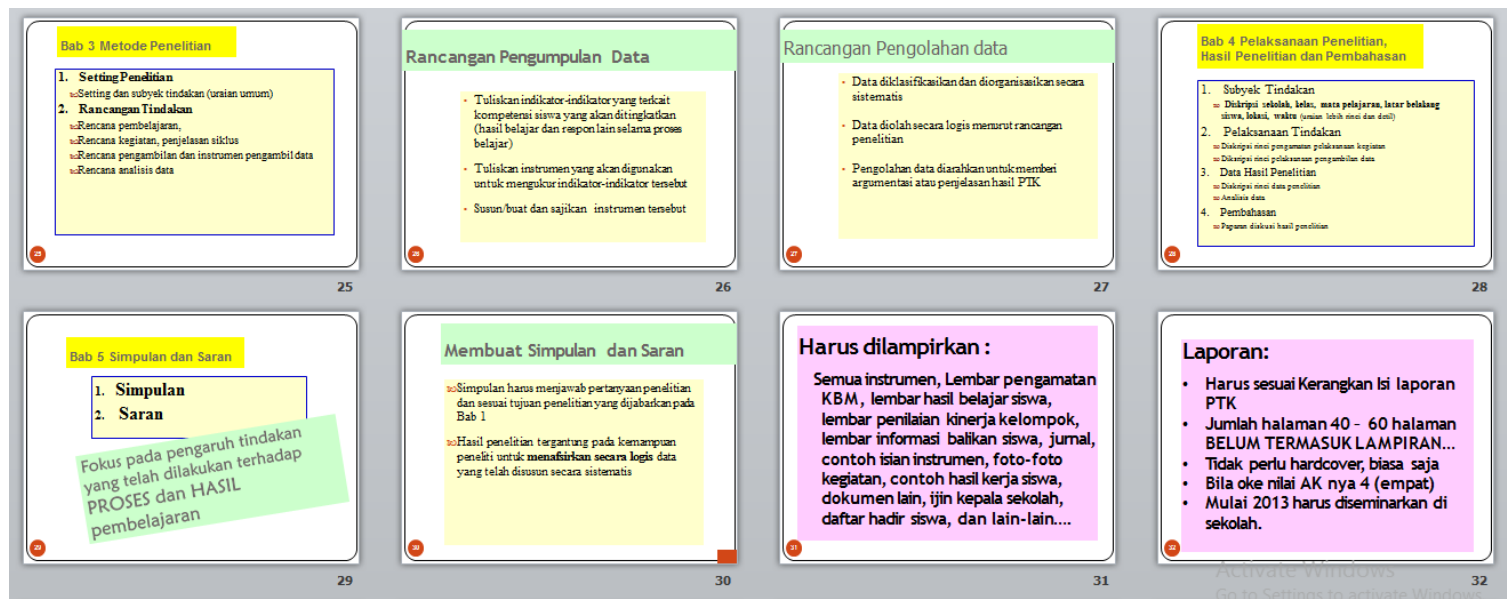

Gambar 3.9. Buku Saku Pedoman Penulisan Karya Ilmiah Bagian 4 


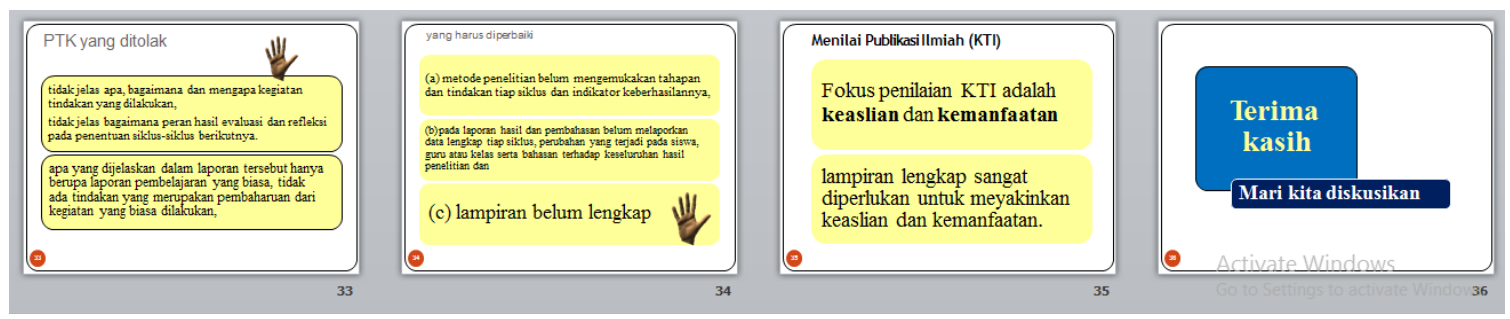

Gambar 3.10. Buku Saku Pedoman Penulisan Karya Ilmiah Bagian 5

\section{KESIMPULAN}

Pelatihan penulisan karya ilmiah terhadap guru-guru di kota Sibolga telah berhasil dilaksanakan tanpa kendala yang cukup berarti. Selain melatih guru untuk menulis karya tulis ilmiah dengan kaidah yang benar, pelatihan juga berfokus untuk menghasilkan guru-guru yang dapat berperan sebagai tutor penulisan karya tulis ilmiah bagi rekannya. Proses pelatihan dilaksanakan secara langsung dengan mematuhi protokol kesehatan dan mengikuti arahan gugus tugas Covid 19 di kota Sibolga terkait dengan pandemi yang sedang berkembang saat ini.

\section{UCAPAN TERIMAKASIH}

Tim pengabdian menyampaikan terimakasih kepada Rektor Universitas Sumatera Utara melalui lembaga pengabdian masyarakat atas program mono tahun dana NON PNBP Universitas Sumatera Utara nomor 287/UN5.2.3.2.1/PPM/2020. Tim juga menyampaikan terimakasih kepada mitra pada kegiatan pengabdian ini.

\section{DAFTAR PUSTAKA}

Bahdin, Nur Tanjung dan Ardial. (2005). Pedoman Penulisan Karya Ilmiah (Proposal, Skripsi, dan Tesis) Dan Mempersiapkan Diri Menjadi Penulis Artikel. Jakarta: Prenada Media

Daryanto. (2013). Standar Kompetensi dan Penilaian Kinerja Guru Profesional. Yogyakarta : Gava Media

Haryanto. (2006). Rambu-rambu dan Kiat Menulis Artikel Ilmiah dalam Upaya Penerbitan Berkala Ilmiah Terakreditasi. Disampaikan dalam Lokakarya Penerbitan Majalah Ilmiah di Jurusan Administrasi Pendidikan Fakultas Ilmu Pendidikan 